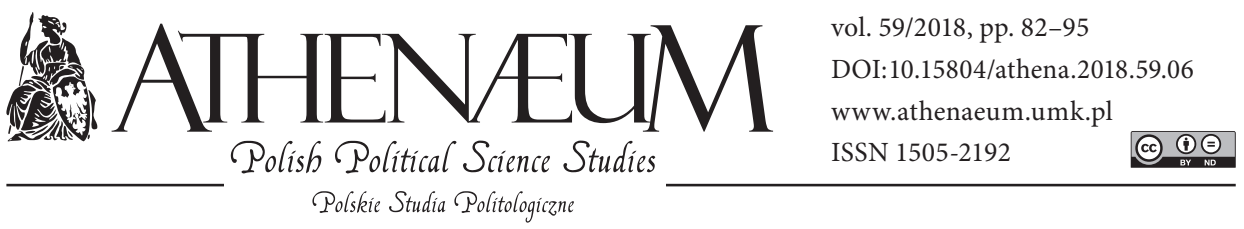

\title{
CIVIL SOCIETY IN SWEDEN AS A FACTOR OF SWEDEN'S IMAGE ATTRACTIVENESS
}

\author{
SPOŁECZEŃSTWO OBYWATELSKIE JAKO CZYNNIK \\ ATRAKCYJNOŚCI WIZERUNKOWEJ SZWECJI
}

\section{Anna Kobierecka*}

\begin{abstract}
In recent years, nation branding attracts interest of scholars and academic environment. In the era of globalisation, the need to care for propoer image and perception of a state in international environment becomes even more apparent. Soft power resources are a vital element in creating a strong nation brand. The aim of the article is to verify hipothesis stating that civil society can be perceived as a soft power resource used in building the brand. Therefore, the proposed research is conducted by analysing most significant branding rankings with respect to the positions reached by Sweden, used as a model state with strong civil society.
\end{abstract}

Keywords: soft power, branding, state attractiveness, civil society, soft power resources

\section{ABSTRAKT}

W ostatnich latach branding narodowy cieszy się coraz większym zainteresowaniem wśród środowisk akademickich. W dobie globalizacji dostrzega się coraz wyraźniej konieczność dbania o odpowiedni wizerunek i postrzeganie państw na arenie międzynarodowej. Istotnym elementem w budowaniu wizerunków państw są zasoby miękkiej siły, jakimi dysponują państwa. Celem artykułu jest weryfikacja hipotezy, zgodnie z którą społeczeństwo obywatelskie może zostać uznane za jeden z cennych zasobów wpływających pozytywnie na budowanie silnej marki państwa. W tym celu analizie poddane zostały najistotniejsze rankingi brandingowe $\mathrm{z}$ uwzględnieniem pozycji uzyskiwanej przez Szwecję, służącą jako państwo modelowe o silnym i rozbudowanym społeczeństwie obywatelskim.

Słowa kluczowe: soft power, branding, zasoby soft power, społeczeństwo obywatelskie, atrakcyjność wizerunkowa państwa

* University of Łódź, Faculty of International and Political Studies. 


\section{INTRODUCTION}

In contemporary world hard power has been exchanged with soft and smart power (Nye, 2007). States that posses significant soft power resources can compete effectively. According to Nye, the creator of the concept of soft power, it encompasses three broad categories: culture, policies, and political values (Nye, 2004). They can include many different factors, among others, heritage, art, historical monuments, natural beauty, etc. Wise exploration of soft power resources is crucial in shaping attractive image of a state. The most significant means of constructing both good reputation and attractiveness are nowadays public diplomacy and nation branding. They both use soft power resources in creating positive associations with states and nations. For example, Eytan Gilboa (2008) presents the idea of nation branding as a process of linking a state with characterictic features, comprising its uniqueness. Nadia Kaneva states that branding by using nation, its identity and social capital increases state's image attractiveness (2011).

The aim of the article is to test a hypothesis that civil society can be perceived as one of soft power resources, which in this case has a crucial meaning to Sweden's attractiveness. In most branding indexes we can find categories of examining the power of brand that are at least to some extent related to civil society and values that are influencing Swedish civil society.

\section{METHODOLOGY}

The analysis proposed in the article has been based on examining the most significant branding indexes - Simon Anholt's Nation Brands Index and FutureBrand's Country Brand Index. In the first part of the article, the concept of civil society is introduced with special regard to the specifity of the Swedish one. In the latter part, possible dependence between the elements of Sweden's attractive image and its civil society are analysed. Other indexes will be taken into consideration as well, for example Global Gender Gap Index, Corruption Perceptions Index, European Commission's European Innovation Scoreboard, 2016 RepTrak Reputation Ranking. The selection of rankings valuable in terms of proposed research has been made on the basis of having any reference to Swedish civil society's values. Sweden's high position in rankings evaluating different aspects of civil society can be viewed as an evidence for relation between civil society and image attractiveness. 


\section{LITERATURE REVIEW}

The concepts of nation branding, soft power and civil society are widely recognised worldwide. Regarding nation branding, such scholars as Simon Anholt (2007, 2008), Jan Melissen (2005), Wally Olins (2002, 2005), Gyorgy Szondi (2010) should be mentioned just to name a few. The linkage between soft power and nation branding is close. For example, Nye (2008) stresses that in the $21^{\text {st }}$ century we can observe new dynamics within international environment where competition between states and politicians is based on image and credibility. The core of politics is „whose story wins". What seems to be significant is the idea of competitive identity presented by Anholt (2007), where the state's image should be built on the basis of true and authentic values. Then, Olins (2005) highlights the fact that contemporary states' competition emerges in brand export, direct foreign investments and tourism, where proper nation branding helps to improve competitiveness by exploring soft power resources. Also Ying Fan (2006) indirectly talks about using soft power resources when conducting nation branding on national level - e.g., Sweden as a welfare state or innovative state. He also talks about branding based on cultural aspects. Szondi (2010) analysed the use of PR in nation branding, which, according to him, allows engagement of the whole society into the proces of image creation. Similar opinion is presented by Melissen (2005), who also sees in the society an important nexus in effective branding strategy. All those scholars' works represent significant references for nation branding and the linkage between this phenomenon and soft power and its resources. They often highlight the importance of society as a whole, culture and certain values as core for branding activities and developing strong nation brand. However, they do not indicate directly that civil society itself can be perceived as a soft power resource and that it can have a significant meaning for the state's attractiveness and the power of brand. Taking Sweden as an example, we can observe that civil society, build with the use of certain values, tradition and historical experience, seems to play an important role in the state's image and brand.

\section{THE IDEA OF CIVIL SOCIETY}

Civil society can be associated with democracies as it is based on respecting political and civil rights, e.g., freedom of associations, or freedom of expression. Such values are in total clash with all authoritarian regimes. However, the exist- 
ence of civil society cannot be simply limited to liberal and stable democracies, as for example civil society in Western European countries emerged already in the times of authoritarianism (Chandhoke, 2007).

The term 'civil society' seems to be rather vague owing to many different theoretical perspectives of analysing this phenomenon. However, it is not impossible to name some core ideas concerning civil society (Jensen, 2006). For example, Rosenblum and Post (2002) state that: "Civil society is a zone of freedom for individuals to associate with others and for groups to shape their norms, articulate their purposes, and determine for themselves the internal structure of group authority and identity" (Rosenblum \& Post, 2002). Therefore, in such perspective, civil society is mostly about pluralism and freedom of association. Such understanding of civil society is especially valuable when considering the Swedish case, where value of free associations is strongly appreciated. What is more, the Swedish civil society is embedded in certain values constituting national identity of Swedes, which will be discussed in the latter part of the article.

Reaching to concepts deriving from David Hume or Adam Smith, it is argued that civil society arises from the citizens' social attachment leading them towards common good. Here, we can perceive civil society as a public sphere which enables individuals to reach their own interests and common good at the same time (Jensen, 2006). Similar understanding of civil society can be found in the works of J. Habermas (1989), where he defines this phenomenon as a space or private persons that create public sphere through defining public goals and common good. Such concept suggests that civil society is a sphere within which citizens can shape their vision of good life and have an opportunity to pursue it.

United Nations and Organisation for Economic Cooperation and Development define civil society as groups functioning outside the government, e.g., labour unions, NGOs, charity organisations, faith-based organisations, migrants and minorities organisations, etc. They are autonomous from the state, voluntary and based on shared rules that allow citizens to cooperate and express their interests and achieve mutual goals (Cheema, 2010). In Sweden, the term 'civil society' is used when describing non-profit cooperatives and communities and all other kinds of social initiatives (Herz, 2016).

What is important to note with regard to the latter analysis, is the fact that civil society is strongly dependant on certain values represented by nation. Those values can be associated with national identity. It results in better and more efficient development and functioning of civil society in some states (e.g., Nordic states) and in weak civil society in others, e.g., Russia (Barabtarlo, 2012). Since 
civil society according to most of its definitions is about pursuing common good, it could be assumed that more cooperative nation with strong feeling of social solidarity should construct stronger civil society.

\section{SWEDISH CIVIL SOCIETY}

Swedish society has a strong tradition of solidarity which seems to be a characteristic of Nordic states (Marklund, 2013). Such tradition simply derives from two different aspects. First, being an agrarian state for a long time, Swedish society became used to acts of solidarity in the times of poverty. The social relations were based on sharing resources and wealth. The second source of social solidarity is the longstanding tradition of welfare state and strong social democratic party in Sweden. Stable governing by SAP in Sweden allowed building a strong state, grounded on the fundaments of solidarity, equality and just distribution of resources and wealth (Barry, Berg, \& Chandler, 2012; Bruun, 2007). Both factors influenced the creation of society strongly displaying solidarity attitudes. What is more, the creation of a welfare state resulted in high quality of life in Sweden, which is one of the core elements of today's strong nation brand. When discussing Swedish civil society, it is vital to mention the tradition of popular movements. The term refers to the concept of folkrörelse, which concerns democratically governed organisations offering open membership (Hvenmark, 2008).

Other value worth mentioning when discussing the specificity of Swedish civil society is the long tradition of both freedom of speech and freedom of associations. Especially freedom of speech, ensured by Tryckfrihetsförordningen (Freedom of Press Act) and also Yttrandefrihetsgrundlagen (Fundamental Law on Freedom of Expression), is a fundamental law in Swedish legal system that has had a significant influence on the shaping of civil society. In 1766, Sweden was the first state in the world to include this law into the constitution (Nergelius, 2011). Also freedom of expression is strongly appreciated in Sweden. Therefore, in Sweden there is a strong tradition of demonstrations and legally provided right of founding organisations that is included in The Swedish Right of Association and Negotiation Act (Summers, 1964). The strongest are labour organisations affiliated in The Swedish Trade Union Confederation (Landsorganisationen i Sverige - LO). According to OECD data from 2014, out of 4279000 employees, 2878000 were trade unions' members, which is $67,3 \%$. In comparison, the OECD average is 
$16,7 \%$ (OECD, 2014). Such figures indicate how active the Swedish society is. The concept of wide social participation in organisations is strongly supported by the state. Even migrants are encouraged to establish their own organisational structures by specially prepared informational leaflets concerning legal aspects and procedures of founding their organisations (Soysal, 1994).

Sweden's external image is based on, among others, an open society where people have the right to participate in demonstrations, freedom of speech, free press, freedom of participating in organisations and the right to scrutinise those in power. All those rights are aimed at creating an equal, open, transparent and tolerant society (Sverige, sweden.se). Such values and wide opportunities of social organisation provide feeling of internal security and stability of a state. It also means wider possibilities of influencing authorities and decision-making procedures. Such assumption is especially true in case of Sweden. Here, the relations between government, trade unions and other non-governmental organisations acquire a specific form of mutual cooperation. As a result, civil society's structures are perceived as a complementary element of the state. Such cooperation between state and civil society already has a long tradition - in 1935, Swedish Social Democratic Party initiated negotiations with LO with regard of enhancing both economy and wealth (Whyman, 2003; Aspalter, 2001). Trade unions and employees themselves became included into decisionmaking process with respect to the solidarity concept and pursuing equal and just society. The cooperation between the state and civil society has been also visible within immigration organisations. The functioning of such organisations has been subsidised by the state. Since 1975 government provides special grants especially supporting cultural activities (Lundberg-Lithman, 1987). Also religious communities were financially supported. What is more, since 1997 representatives of immigrant organisations are invited to participate in the Government's Council for Ethnic Equality and Integration (Vukusic, 1999). This decision allowed inclusion of migrants' perspective on integration policy in Sweden and its further development. Religious organisations that should be mentioned as well are, among others, the Christian Council of Sweden (Sveriges Kristna Råd), the Muslim Council of Sweden (Sveriges Muslimska Råd) or the Muslim Association of Sweden (Sveriges Muslimska Förbund). Other significant organisations constituting civil society are women organisations, gathered under the Swedish Women's Lobby. The lobby consists of 44 women organisations with the aim to improve women's position within the Swedish society (Sveriges Kvinnolobby, sverigeskvinnolobby.se). 
Swedish civil society plays a significant role in general development of the state. Swedish trade unions, being a significant element of civil society, have an impact not only on legal aspects, but are engaged in coordinating education aspects, gender equality and social security as well (Sverige, lo.se). LO is therefore committed to political development within the mentioned areas. What is more, trade unions are engaged in Fairtrade certification scheme, taking care of high quality products meeting standards based on human rights in working life (Sverige, lo.se). In this way, civil society contributes not only to the well being of employees, but to the general perceptions of Sweden abroad as well, especially in the context of certain values - equality, wealth, tolerance, society's reputation, or quality products.

\section{CIVIL SOCIETY AS SOFT POWER RESOURCE IN SWEDEN}

The creation of nation brand is closely related to national identity. This consists of common culture (represented by language, literature, values, people, etc.), common symbols and historical memory, when discussing ethnical national identity. Here, national identity has a historical dimension related to previous forms of collective identity (Smith, 2009; Smith, 1995). We can also distinguish civic national identity, based rather on common laws and civic responsibilities (Baycroft \& Hewitson, 2006). National identity is one of the core elements of shaping nation's brand. According to Nadia Kaneva (2011), the nation, its identity and social capital can be used in a political manner and influence the shape of a nation's brand. In such understanding, the identity of a nation brand has a lot in common with nation's identity itself. The brand identity is based on the most attractive aspects of a certain state, e.g., values, culture, nature or most reputable and well known products that are used in creating and further shaping of an attractive state's image. Simon Anholt even considers nation brand and national identity to be the same: "National identity and nation brand are virtually the same thing: nation brand is national identity made tangible, robust communicable, and above all useful" (Anholt, 2007). Taking into consideration that nation brand and national identity can be perceived as related to each other, and both are constructed and shaped with the use of soft power resources as culture, values, people, etc., we can assume that civil society, build on the fundaments of certain values and by people, can be considered as a soft power resource. Most reputable branding indexes can serve as a confirmation of this 
assumption, in spite of the fact that they do not include it itself as one of the indicators.

Sweden has a strong nation brand, which has been created with the use of soft power resources. In the Simon Anholt and GfK Nation Brands Index, Sweden reached the $10^{\text {th }}$ position (Simon Anholt and GfK Nation Brands Index). In FutureBrand's Country Brand Index 2014-15, Sweden is the fourth state according to its brand strength and is included in the category of country brands (FutureBrand, 2014-15).

The soft power resources can be grouped into certain categories. Such categorisation has been proposed by Simon Anholt and FutureBrand. Anholt's hexagon proposes following categories of resources that should be considered when measuring the strength of nation brand.

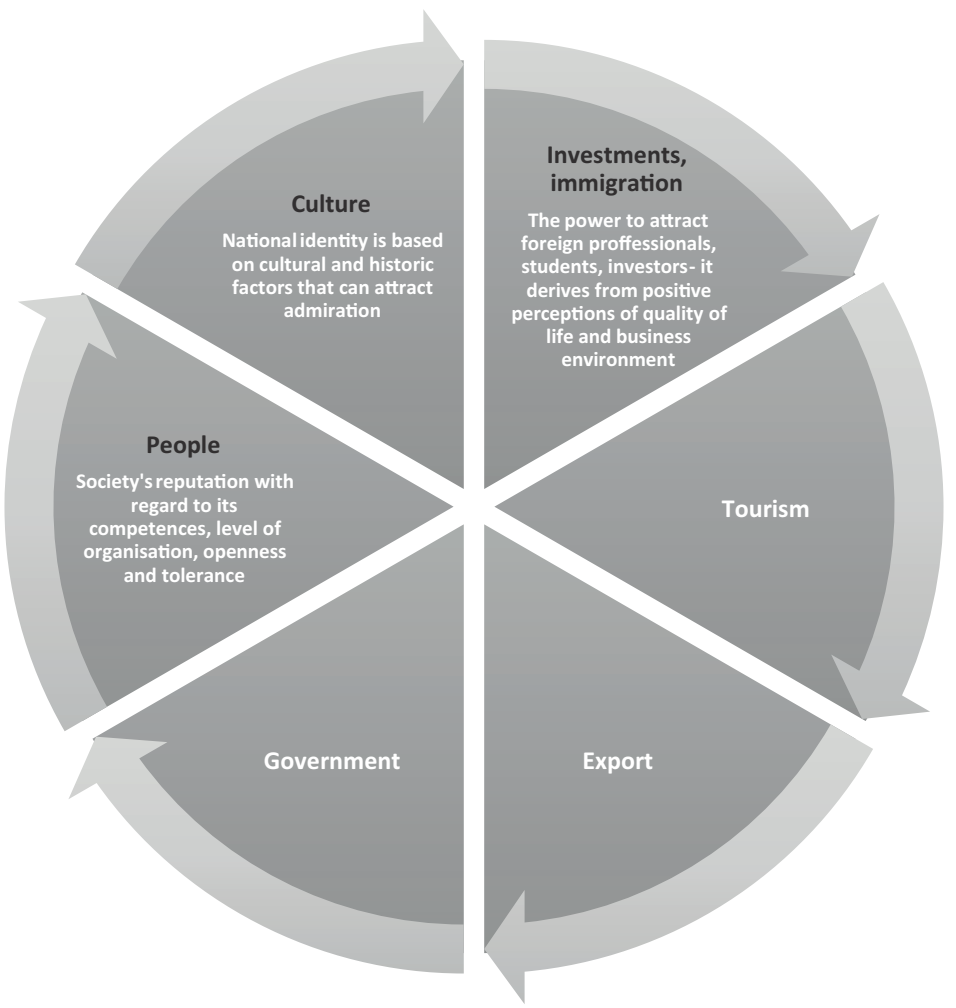

Picture 1. Simon Anholt's Hexagon, with highlighted categories related to Swedish civil society

Source: Simon Anholt and GfK Nation Brands Index, http://nation-brands.gfk.com. 
The author decided to highlight three categories of soft power resources from Nation Brands Index which had any relevance to Swedish civil society. Those are: people, culture, and investments and immigration. In the 'people' category, reputation, competences, level of organisation, openness and tolerance are taken into consideration. The analysis conducted in the part concerning Swedish civil society showed that strong civil society represented mostly by trade unions contributes to society's reputation with respect to its competences (among others, trade unions are engaged in educational activities of both employees and children). Wide engagement of trade unions in decisionmaking processes and wide participation of employees also indicate high level of organisation of Swedish society. The second category is culture, as national identity is culturally based as well. Here, such historically grounded values as feeling of solidarity and cooperative tendencies should be mentioned. Those are values strongly affecting existence of solid civil society. According to theoretical understanding of civil society, one of its characteristics is solidarity in pursuing goals perceived as common for the society. The third category, 'investment and immigration', again refers strongly to the role of trade unions, but Social Democrats as well. Those actors strive for higher quality of life by providing social care and protecting employees' rights and interests. The higher quality of life is, the wider interest in a state among students and professionals can be observed.

Similar observations can be made when considering Country Brand Index. Here Sweden tops in the category of value system and quality of life. The first category includes subcategory of political freedom. As indicated above, freedom of speech and freedom of expression are one of the most fundamental rights in Sweden. Wide possibilities of associations, organisations and demonstrations contribute to both transparency in political life, higher stability, feeling of influence on politics and feeling of internal security. All this is provided by civil society's structures - trade unions, religious organisations, immigrant organisations, women organisations and many more. Such organisation of Swedish civil society impacts Sweden's attractiveness.

The second most successful category is 'quality of life', which includes standard of living, safety and security. Again, influence of civil society can be observed taking into consideration the engagement of most of the non-governmental organisations into decision-making processes and their actual contribution to safeguarding rights of all citizens (and legal migrants as well when considering immigrant organisations' role in public life). 


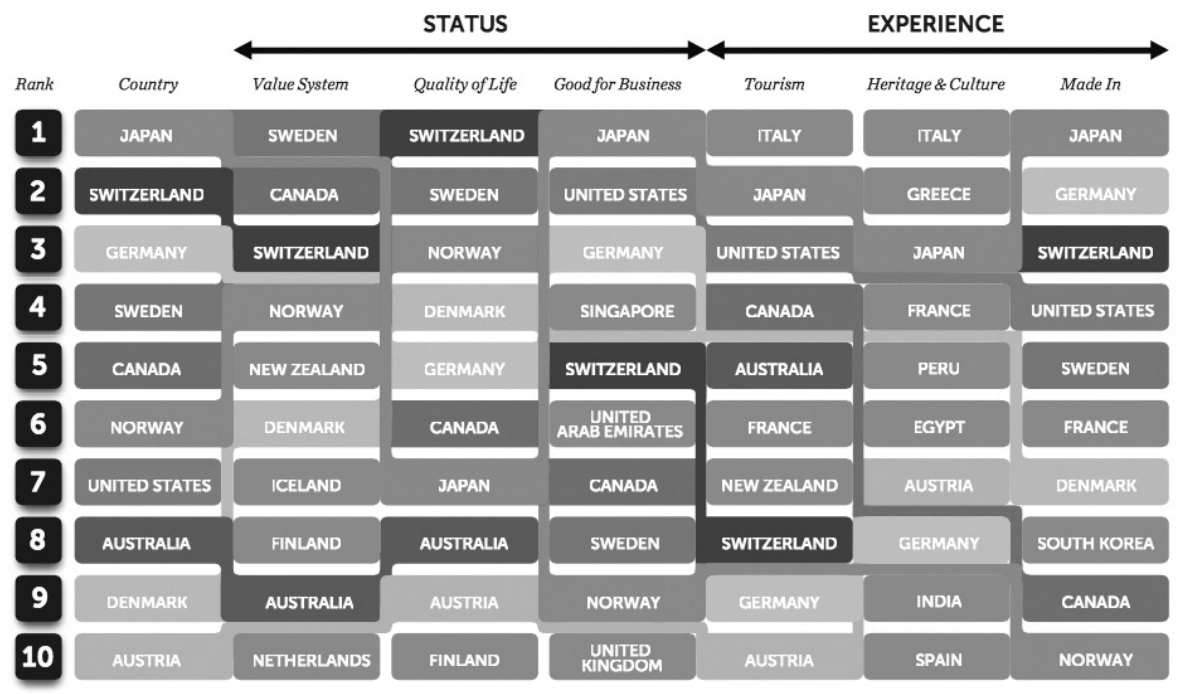

Picture 2. Country Brand Index 2014-15 - ranking by dimensions

Source: FutureBrand, Country Brand Index 2014-15.

Other rankings worth mentioning when discussing whether civil society can be perceived as soft power resource are 2016 RepTrak Reputation Ranking, Global Gender Gap Index, Corruption Perceptions Index and European Commission's European Innovation Scoreboard. In RepTrak Reputation Ranking, Sweden ranked first. The highest scores obtained by Sweden applied to welfare state aspects (parental leave and free day care services), being a safe country for women and with high transparency in media (Reputation Institute, 2016). Those derive at least to some extent from civil society - welfare support has been developed systematically by civil societies' structures. According to Global Gender Gap Index, Sweden is the fourth country in the world considering gender equality (Reputation Institute, 2016). Again, such high score derives from strong position of women's organisations in Sweden. In Corruption Perceptions Index, Sweden ranked third (Transparency International, 2015). Transparency in public and political life is an important part of Swedish civil society, where all nongovernmental organisations are aimed at not only active participation in policy making and decision-making processes, but also at controlling the government. The last ranking is the European Innovation Scoreboard, where Sweden again is one of the top countries, reaching second position. The indicators taken into 
account in the ranking are, among others, human resources and innovators (European Commission, 2016). People and their competences and reputation are one of the soft power categories in assessing the power of nation brand. Swedish civil society through trade unions and focus put on human resources development influence positive perception of Swedish human resources as well as perception of Sweden as business friendly and innovative country.

\section{SUMMARY}

Civil society is a broadly developed, historically and socially based phenomenon that plays an important role not only in developing a strong and stable state, but a state with positive image as well. However, civil society itself is not named as a single indicator measuring nation brand strength in the most important international rankings. The categories of soft power resources used in creating a strong nation brand can be connected with the elements of civil society. In the theoretical part of the article, the proximity of national identity, which undoubtedly is influencing the character of Swedish civil society, and brand identity itself have been analysed. It allows confirming the assertation that civil society, in case of Sweden, can be perceived as one of soft power resources used in building strong brand. As confirmation of this statement, the analysis of most significant branding rankings has been conducted, which showed that the categories in which Sweden reached top score are related to the core elements constructing Swedish civil society. Based on solidarity, freedom of speech and expression, Sweden developed a strong network of voluntary and far-reaching organisations influencing the shape of welfare state, contributing to high quality of life, transparency, equality and qualified human resources.

\section{REFERENCES:}

Anholt, S. (2007). Competitive Identity: The New Brand Management for Nations, Cities and Regions. New York: Palgrave Macmillan.

Anholt, S. (2008). From Nation Branding to Competitive Identity: The Role of Brand Management as a Component of National Policy. In: K. Dinnie (ed.), Nation Branding: Concepts, Issues, Practice (pp. 22-33). Oxford, UK: Butterworth-Heinemann.

Anholt, S. (2015). GfK Nation Brands Index. Retrieved from: http://nation-brands.gfk. com. 
Aspalter, C. (2001). Importance of Christian and Social Democratic Movements in Welfare Politics. New York: Nova Science.

Barabtarlo, A. (2012). Charles Timberlake's Unfinished Project: The Ivan Petrunkevich Letters (1886-1928). In: C.E. Timberlake, \& A.K. Wise (eds.), Cultural Identity and Civil Society in Russia and Eastern Europe: Essays in Memory of Charles E. Timberlake (pp. 28-38). Newcastle upon Tyne: Cambridge Scholars Publishing.

Barry, J., Berg, E., \& Chandler, J. (2012). Embedding European Identity in Context: Changing Social Solidarities in Europe. In: M. Ellison (ed.), Reinventing Social Solidarity Across Europe (pp. 83-98). Bristol: The Policy Press.

Baycroft, T., \& Hewitson, M. (2006). Introduction. In: T. Baycroft, \& M. Hewitson (eds.), What is a Nation? Europe 1789-1914 (pp. 1-13). Oxford: Oxford University Press. Bruun, N. (2007). The Vaxholm Case and Its "Solidarity Lessons" from a Swedish and European Perspective. In: L. Magnusson, \& B. Strath (eds.), European Solidarities: Tensions and Contentions of a Concept (pp. 121-134). Brussels: P.I.E. Peter Lang s.a. Chandhoke, N. (2007). Civil Society. Development in Practice, 17(4-5), 607-614.

Cheema, G.S. (2010). Civil Society Engagement and Democratic Governance: An Introduction. In: V. Popovski, \& G.S. Cheema (eds.), Engaging Civil Society: Emerging Trends in Democratic Governance (pp. 1-20). Tokyo: United Nations University Press.

European Commission (2016). European Innovation Scoreboard 2016. Retrieved from: http://ec.europa.eu/growth/industry/innovation/facts-figures/scoreboards_pl.

Fan, Y. (2006). Branding the Nation: What Is Being Branded? Journal of Vacation Marketing, 12(1), 5-14.

FutureBrand (2014-2015). Country Brand Index 2014-15. Retrieved from: http://www. futurebrand.com/uploads/CBI-14_15-LR.pdf.

Gilboa, E. (2008). Searching for a Theory of Public Diplomacy. The Annals of the American Academy of Political and Social Science, 616, 55-77. doi: 10.1177/ 000 2716207312142.

Habermas, J. (1989). The Structural Transformation of the Public Sphere: An Inquiry into a Category of Bourgeois. Cambridge: MIT Press.

Herz, M. (2016). “Then We Offer Them a New Project" - The Production of Projects in Social Work Conducted by Civil Society in Sweden. Journal of Civil Society, 12(4), 365-379.

Hvenmark, J. (2008). Reconsidering Membership: A study of Individual Members' Formal Affiliation with Democratic Governed Federations. Stockholm: Stockholm School of Economics, EFI.

Jensen, M.N. (2006). Concepts and Conceptions of Civil Society. Journal of Civil Society, 2(1), 39-56.

Kaneva, N. (ed.) (2011). Branding Post-Communist Nations: Marketizing National Identities in the New Europe. London: Routledge.

Landsorganisationen i Sverige. Retrieved from: www.lo.se. 
Lundberg-Lithman, E. (1987). Immigration and Immigrant Policy in Sweden. Stockholm: Swedish Institute.

Marklund, C. (2013). A Swedish Norden or a Nordic Sweden? Image Politics in the West During the Cold War. In: J. Harvard, \& P. Stadius (eds.), Communicating the North: Media Structures and Images in the Making of the Nordic Region (pp. 263-287). Farnham: Ashgate.

Melissen, J. (2005). The New Public Diplomacy: Between Theory and Practice. In: J. Melissen (ed.), The New Public Diplomacy: Soft Power in International Relations (pp. 3-27). Clingendael: Palgrave Macmillan.

Nergelius, J. (2011). Constitutional Law in Sweden. Alphen aan den Rijn: Kluwer Law International.

Nye, J.S., Jr. (2007). Soft Power: The Means to Success in World Politics. New York: Public Affairs.

Nye, J.S., Jr. (2008). Public Diplomacy and Soft Power. The ANNALS of the American Academy of Political and Social Science, 616, 94-109. DOI: 10.1177/0002716207311699.

OECD (2014). Union Members and Employees. Retrieved from: https://stats.oecd.org/ Index.aspx?DataSetCode=U_D_D.

Olins, W. (2002). Branding the Nation - The Historical Context. Journal of Brand Management, 9(4-5), 241-248.

Olins, W. (2005). Making a National Brand. In: J. Melissen (ed.), The New Public Democracy: Soft Power in International Relations (pp. 169-179). Clingendael: Palgrave Macmillan.

Reputation Institute (2016). Global Gender Gap Report 2016. Retrieved from: https:// reports.weforum.org/global-gender-gap-report-2016/.

Rosenblum, N., \& Post, R. (eds.) (2002). Civil Society and Government. NJ: Princeton University Press.

Smith, A.D. (1991). National Identity. London: Penguin.

Smith, A.D. (1995). Nations and Nationalism in a Global Era. Cambridge: Polity.

Soysal, Y.N. (1994). Limits of Citizenship: Migrants and Postnational Membership in Europe. Chicago: University of Chicago Press.

Summers, C.W. (1964). Freedom of Association and Compulsory Unionism in Sweden and the United States. Faculty Scholarship Series, 3918, 647-696. Retrieved from: http://digitalcommons.law.yale.edu/fss_papers/3918.

Sverige. Retrieved from: www.sweden.se.

Sveriges Kristna Råd. Retrieved from: http://www.skr.org.

Sveriges Kvinnolobby. Retrieved from: http://sverigeskvinnolobby.se/en/members/.

Sveriges Muslimska Förbund. Retrieved from: http://www.smf-islam.se.

Sveriges Muslimska Råd. Retrieved from: http://www.sverigesmuslimskarad.org.

Szondi, G. (2010). From Image Management to Relationship Building: A Public Relations Approach to Nation Branding. Place Branding and Public Diplomacy, 6(4), 333-343. DOI: 10.1057/pb.2010.32.

Transparency International (2015). Corruption Perceptions Index 2015. Retrieved from: https://www.transparency.org/cpi2015/. 
Vukusic, D. (1999). Experiences of the Croatian National Association in the Participation of Immigrants in Sweden. In: H. Entzinger et al., Political and Social Participation of Immigrants through Consultative Bodies (pp. 97-100). Strasbourg: Council of Europe Publishing.

Whyman, P. (2003). Sweden and the 'Third Way': A Macroeconomic Evaluation. Aldershot: Ashgate. 